\title{
Acetamiprid, carbendazim, diuron and thiamethoxam sorption in two Brazilian tropical soils
}

\author{
LEANDRO CARBO ${ }^{1}$, EUCARLOS L. MARTINS ${ }^{1}$, ELIANA F. G. C. DORES ${ }^{1}$, CLÁUdIO A. SPADOTTO ${ }^{2}$, \\ OSCARLINA L. S. WEBER ${ }^{3}$ and ERMELINDA M. DE-LAMONICA-FREIRE ${ }^{4}$ \\ ${ }^{1}$ LARB - Laboratório de Análises de Residuos de Biocidas, Universidade Federal de Mato Grosso, Cuiabá, MT, Brazil \\ ${ }^{2}$ Embrapa Meio Ambiente, Jaguariüna, São Paulo, Brazil \\ ${ }^{3}$ FAMEV - Faculdade de Agronomia e Medicina Veterinária, Universidade Federal de Mato Grosso, Cuiabá, MT, Brazil \\ ${ }^{4}$ UNIVAG Centro Universitário, Värzea Grande, MT, Brazil
}

Sorption of acetamiprid ((E)-N1-[(6-chloro-3-pyridyl)methyl]-N2-cyano-N1-methylacetamidine), carbendazim (methyl benzimidazol-2-ylcarbamate), diuron (N-(3,4-dichlorophenyl)-N,N-dimethyl urea) and thiamethoxam (3-(2-chloro-thiazol-5ylmethyl)-5-methyl-[1,3,5] oxadiazinan-4-ylidene-N-nitroamine) was evaluated in two Brazilian tropical soils, Oxisol and Entisol, from Primavera do Leste region, Mato Grosso State, Brazil. To describe the sorption process, batch experiments were carried out. Linear and Freundlich isotherm models were used to calculate the $K_{d}$ and $K_{f}$ coefficients from experimental data. The $\mathrm{K}_{d}$ values were utilized to calculate the partition coefficient normalized to soil organic carbon $\left(K_{o c}\right)$. For the pesticides acetamiprid, carbendazim, diuron and thiamenthoxan the $\mathrm{K}_{o c}\left(\mathrm{~mL} \mathrm{~g}^{-1}\right)$ values ranged in both soils from $98-3235,1024-2644,145-2631$ and $104-2877$, respectively. From the studied pesticides, only carbendazim presented correlation $\left(r^{2}=0.82\right.$ and $\left.p<0.01\right)$ with soil organic carbon (OC) content. Acetamiprid and thiamethoxam showed low sorption coefficients, representing a high risk of surface and ground water contamination.

Keywords: Sorption isotherm; groundwater; organic carbon; High Performance Liquid Chromatography-Diode Array Detector; contamination.

\section{Introduction}

Agriculture activities have been intensified for the last 20 years in the Brazilian savanna region. The monocultures grown there demand a high degree of mechanization and input of agrochemicals, in particular synthetic pesticides ${ }^{[1]}$ Intensive use of pesticides in agriculture may cause environmental pollution, such as the contamination of soil, surface and ground water and pose risks to human health due to residues in food and drinking water. ${ }^{[2-7]}$ Pesticides can follow different routes from the soil: retention in organic and/or mineral soil fraction, chemical, photochemical and biological degradation, volatilization, runoff and leaching. $\left.{ }^{[8}-11\right]$

The sorption is an important factor regulating pesticides behavior in the environment, being useful information to

\footnotetext{
Address correspondence to Leandro Carbo, LARB - Laboratório de Análises de Residuos de Biocidas, Departamento de Quimica, Universidade Federal de Mato Grosso, Av. Fernando Corrêa da Costa, s/n, Cuiabá, MT, Brazil; E-mail: carboquimico@hotmail. com.

Received October 9, 2006.
}

foresee the contamination potential of surface and ground water so it is important to understand the sorption processes and its relationship with soil parameters. ${ }^{[12-15]}$ Some pesticide properties, which influence sorption to the soil particles are water solubility, vapor pressure, octanol-water partition coefficient and acid-base ionization constant for ionizable compounds. ${ }^{[16-20]}$ In the soils, mineral composition and soil organic matter are important factors affecting sorption of pesticides. ${ }^{[8,9,14,21-28]}$

In Brazil, carbendazim, acetamiprid, diuron and thiamethoxam are pesticides commonly used in cotton and soybean crops. However, there are few studies that evaluate their behavior in tropical climate. ${ }^{[12,13]}$ There are only limited data available on the sorption of carbendazim, ${ }^{[13,16,29]}$ diuron ${ }^{[12,14,15,30]}$ and especially for acetamiprid, and thiamethoxam. ${ }^{[31]}$ Moreover, studies on sorption of pesticides on different soil horizons are practically non-existent. Thus, this work aimed: (i) to determine the sorption of acetamiprid, carbendazim, diuron and thiamethoxam in two Brazilian tropical soils (Entisol and Oxisol) with different physical and chemical properties, such as soil type, $\mathrm{pH}$, organic matter and mineral components; (ii) to compare the sorption behavior of the studied 
pesticides with available data from the literature. This information will contribute to the better understanding of the dynamics of pesticides in tropical environments.

\section{Materials and Methods}

\section{Chemicals and solutions}

Pesticide primary standards of carbendazim $(97.0 \%$ purity) and acetamiprid $(95.0 \%)$ from Ehrenstorfer Quality and diuron $(98.8 \%)$ and thiamethoxam $(99.5 \%)$ from Syngenta were acquired. Methanol and acetonitrile [Mallinckrodt Ultimar, high performance liquid chromatograph (HPLC)], water ultrapure grade Milli- $\mathrm{Q}^{\mathrm{R}}(18 \mathrm{M} \Omega \mathrm{cm})$ and anhydrous calcium chloride $\left(\mathrm{CaCl}_{2}\right.$, J. T. Baker) were used. Quantitative filter paper (Filtrar) $125 \mathrm{~mm}$ diameter and fiber glass membrane (Sartorius GMF 3) 47 mm diameter and $0.4 \mu \mathrm{m}$ porosity were utilized for filtration of the solution deriving from the sorption assay. Stock solutions of each pesticide were prepared in acetonitrile at a concentration level of $100 \mu \mathrm{g} \mathrm{mL}^{-1}$ and maintained under refrigeration. Working standard solutions were prepared by diluting stock solutions as required, for chromatographic analysis. For the sorption experiments, stocks solutions were prepared from the primary standards, in methanol at $100 \mu \mathrm{g} \mathrm{mL}^{-1}$.

\section{Soil sampling}

Two trenches were opened, one in an Oxisol and another in an Entisol, which were characterized in the soil's horizons. Soil samples were collected in three replicates in four horizons of the Oxisol (Ap, A/B, Bwl and Bw2) and in three horizons of Entisol (A, C1 and $\mathrm{C} 2$ ) from the Primavera do Leste region, Mato Grosso State, Brazil, located at $15^{\circ} 25^{\prime}$ latitude South and $54^{\circ} 32^{\prime}$ longitude West. The chemical and physical properties of the soil were characterized using methods described by Embrapa ${ }^{[32]}$ The soil organic carbon (OC) was determined by Walkley-Black's method.

\section{Sorption experiments}

Soil samples were air-dried for $48 \mathrm{~h}$, sieved through a \#10 metal sieve (Tyler equivalent 9 mesh, opening $2 \mathrm{~mm}$ ). Sorption assays were performed according to the method described by Souza et al. ${ }^{[14]}$ where $5.0 \mathrm{~g}$ of soil was weighed in $125 \mathrm{~mL}$-erlenmeyer and $25 \mathrm{~mL}$ of calcium chloride $\left(\mathrm{CaCl}_{2}\right)$ solution $0.01 \mathrm{~mol} \mathrm{~L}^{-1}$ were added, used as a background electrolyte to mimic realistic soil ionic strength and to help flocculation of clay particles. ${ }^{[15,33]}$ This mixture was fortified with each pesticide by adding proper aliquots of stock solutions (c.a. $100 \mu \mathrm{g} \mathrm{mL}^{-1}$ ) prepared in methanol in order to reach increasing concentrations: $1.0 ; 2.0 ; 4.0$; 8.0 and $16.0 \mu \mathrm{g} \mathrm{mL}^{-1}$. The soils were agitated in a mechanical shaker at $140 \mathrm{rpm}$ for 24 hours, to reach equilibrium. All experiments were performed in duplicate and one blank sample was included in every sample batch to check for interfering peaks. Several authors have demonstrated that generally pesticide equilibrium in the batch solution is reached in less than $24 \mathrm{~h} .{ }^{[15,34,35]}$ Therefore, the $24 \mathrm{~h}$-shaking period was chosen. The solution was filtered through a quantitative filter paper followed by glass fiber membrane $(0.45 \mu \mathrm{m})$ and $1.0 \mathrm{~mL}$ aliquot from the filtrate was transferred to an autosampler vial and analyzed by High Performance Liquid Chromatography/with Diode Array Detector (HPLC-DAD).

For sorption coefficient determination the Linear and Freundlich models were utilized. For the Linear model, regression analysis was made by plotting the amount of sorbed pesticide per unit of soil mass $(\mathrm{X} / \mathrm{Ms})$ as a function of the pesticide concentration in the solution in equilibrium (Ce), as demonstrated in the Equation 1:

$$
\frac{X}{M s}=K_{d} \cdot C e
$$

In turn, the Freundlich sorption isotherm was determined through Equation 2:

$$
\frac{X}{M s}=K_{f} \cdot C e^{1 / n}
$$

where, $\mathrm{X} / \mathrm{Ms}$ is the amount of sorbed pesticide per unit of soil mass $\left(\mathrm{mg} \mathrm{kg}^{-1}\right), \mathrm{Ce}$ is the pesticide concentration in equilibrium in the solution $\left(\mathrm{mg} \mathrm{L}^{-1}\right), \mathrm{K}_{f}$ is the Freundlich sorption coefficient and $1 / \mathrm{n}$ is the linearity coefficient of the isotherm.

Partition coefficient normalized to organic carbon $\left(\mathrm{K}_{c c}\right)$ was calculated from $\mathrm{K}_{d}$ and the percentage of organic carbon present in the soil sample, according to Equation 3:

$$
K_{o c}=\frac{K_{d}}{\% C O} \times 100
$$

\section{Statistical analysis}

The kruskal-Wallis non-parametric test was used to compare the $\mathrm{K}_{d}, \mathrm{~K}_{f}$ and $1 / \mathrm{n}$ parameters for each soil horizon. The relationship between those $\mathrm{K}_{d}, \mathrm{~K}_{f}$ and $\mathrm{K}_{o c}$ values with $\mathrm{pH}, \mathrm{OC}(\% \mathrm{OC})$ and $\%$ clay content were determined by regression analysis using the Pearson test $(\mathrm{p}<0,05)$ aiming to verify the influence of these soil properties on the sorption of the studied pesticides.

\section{Instrumentation and operating conditions}

The concentration of pesticides was determined using a high performance liquid chromatograph with diode array UV detector (HPLC/DAD), Varian equipped with a quaternary pump, model 240 , automatic injector model 410 , variable wavelength diode array detector (UV-DAD) model 330 and chromatographic column with stationary phase OmniSpher C18 (particle size $5 \mu \mathrm{m}$ ), $25 \mathrm{~cm}$ long, 4.6 mm inside diameter and $3 / 8$ inches of external diameter. 

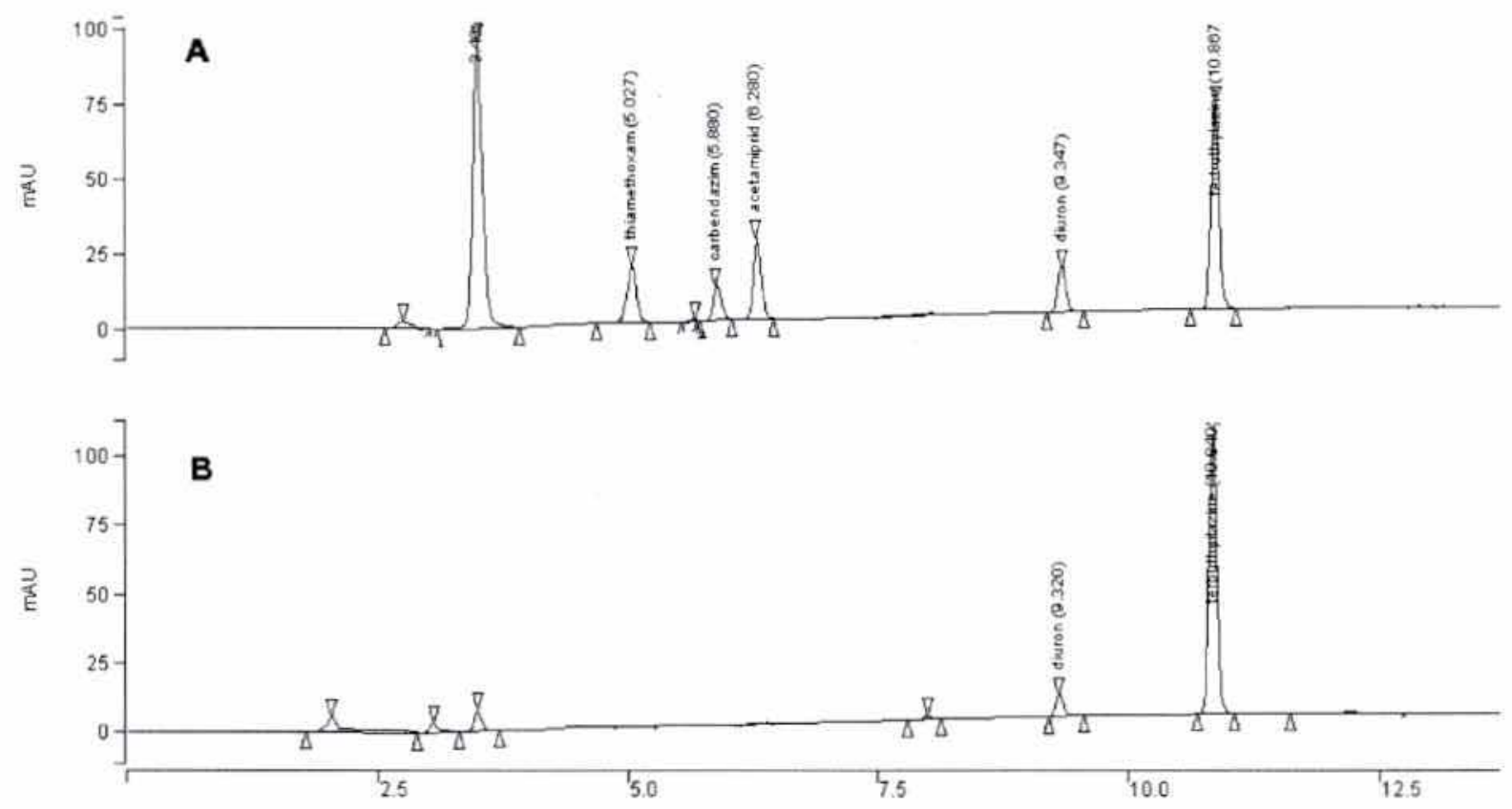

Fig. 1. HPLC chromatograms: (a) standard solution of thiamethoxam, carbendazim, acetamiprid and diuron at $5.0 \mu \mathrm{g} \mathrm{mL}^{-1} \mathrm{and}$ (b) sorption test of diuron at $4.0 \mu \mathrm{g} \mathrm{mL}^{-1}$.

For HPLC analysis, an aliquot $(10 \mu \mathrm{L})$ was injected into the column and eluted at room temperature with constant flow rate of $1.0 \mathrm{~mL} \mathrm{~min}^{-1}$ under the following gradient conditions: initiating with acetonitrile-water at 25:75 the content of acetonitrile was increased linearly to $100 \%$ at $15 \mathrm{~min}$ and held at this composition for $3 \mathrm{~min}$. The chromatograms were recorded at a wavelength of $230 \mathrm{~nm}$ and retention times were: $5.0 \mathrm{~min}$ for thiamethoxan, $5.8 \mathrm{~min}$ for carbendazim, $6.2 \mathrm{~min}$ for acetamiprid, and $9.3 \mathrm{~min}$ for diuron (Fig. 1). The detection and quantification limits of the method were: 0.08 and $0.40 \mu \mathrm{g} \mathrm{L}^{-1}$ for thiamethoxam, 0.11 and $0.41 \mu \mathrm{g} \mathrm{L}^{-1}$ for carbendazim, 0.06 and $0.40 \mu \mathrm{g} \mathrm{L}^{-1}$ for acetamiprid, 0.07 and $0.42 \mu \mathrm{g} \mathrm{L}^{-1}$ for diuron, respectively.

\section{Results and Discussion}

The mean values of the soil sample properties are given in Table 1. There was a relatively wide range of OC from 0.32 to $1.56 \%$ in Oxisol and from 0.48 to $1.40 \%$ in Entisol.

Kaolinite and gibbsite were the major minerals in the Oxisol horizons Bw1 and Bw2, with contents of 219 (Bw1) and $324\left(\mathrm{Bw} 2 \mathrm{~g} \mathrm{~kg}^{-1}\right.$ of kaolinite and 182 (Bw1) e 206 (Bw2) $\mathrm{g} \mathrm{kg}^{-1}$ of gibbsite. Minor quantities of goethite (58 and $\left.68 \mathrm{~g} \mathrm{~kg}^{-1}\right)$ and hematite $\left(6\right.$ and $\left.9 \mathrm{~g} \mathrm{~kg}^{-1}\right)$ were present. Iron and aluminum oxides in the Oxisol horizons ( $\mathrm{Ap}, \mathrm{Bw}$ e Bw2) ranged from 40 to 52 and from 166 to $280 \mathrm{~g} \mathrm{~kg}^{-1}$,

Table 1. Selected properties of Oxisol and Entisol used in sorption isotherm experiments

\begin{tabular}{|c|c|c|c|c|c|c|c|c|}
\hline \multirow[b]{2}{*}{ Soil } & \multirow[b]{2}{*}{$H^{b}$} & \multirow[b]{2}{*}{ Depth $(\mathrm{cm})$} & \multicolumn{2}{|c|}{$p H$} & $O C^{u}$ & Sand & Clay & Clay $/ O C$ \\
\hline & & & $\mathrm{H}_{2} \mathrm{O}$ & $\mathrm{CaCl}_{2}$ & \multicolumn{4}{|c|}{$(\%)$} \\
\hline \multirow[t]{4}{*}{ Oxisol } & Ap & $0-20$ & 5.92 & 4.70 & 1.56 & 63 & 33 & 21.2 \\
\hline & $\mathrm{A} / \mathrm{B}$ & $20-40$ & 5.30 & 4.60 & 1.47 & 70 & 27 & 18.4 \\
\hline & Bw1 & $40-92$ & 5.09 & 4.90 & 0.99 & 63 & 35 & 35.4 \\
\hline & Bw2 & $92-178$ & 5.77 & 5.10 & 0.32 & 63 & 35 & 109.4 \\
\hline \multirow[t]{3}{*}{ Entisol } & A & $8-43$ & 5.00 & 4.30 & 1.40 & 66 & 32 & 22.9 \\
\hline & $\mathrm{Cl}$ & $52-84$ & 4.98 & 4.50 & 0.73 & 60 & 40 & 54.8 \\
\hline & $\mathrm{C} 2$ & $84-114$ & 5.05 & 4.20 & 0.48 & 60 & 37 & 77.1 \\
\hline
\end{tabular}

"organic carbon; "soil horizons

OC: organic carbon. 
Table 2. Acetamiprid sorption parameters for Freundlich and Linear models with confidence interval. Different capital letters within each column denote significant differences at $\mathrm{p}<0.05$ (Kruskal-Wallis non-parametric test)

\begin{tabular}{|c|c|c|c|c|c|c|c|c|c|c|}
\hline Soil & Hor. & $\begin{array}{c}K d^{a} \\
m L g^{-1}\end{array}$ & IC $95 \%$ & $r^{2}$ & $\begin{array}{c}K o c^{b} \\
m L g^{-1}\end{array}$ & $\begin{array}{c}K f^{c} \\
\mu g^{1-1 / n} g^{-1} m L^{1 / n}\end{array}$ & IC $95 \%$ & $r^{2}$ & $l / n^{d}$ & IC $95 \%$ \\
\hline \multirow[t]{4}{*}{ Oxisol } & Ap & $1.95 \mathrm{~A}$ & $1.39-2.51$ & 0.889 & 125 & $1.99 \mathrm{~A}$ & $1.49-2.66$ & 0.955 & $0.981 \mathrm{AB}$ & $0.791-1.171$ \\
\hline & $A / B$ & $1.66 \mathrm{~B}$ & $1.44-1.88$ & 0.957 & 113 & $1.77 \mathrm{~A}$ & $1.40-2.24$ & 0.960 & $0.955 \mathrm{~A}$ & $0.796-1.113$ \\
\hline & Bwl & $0.97 \mathrm{C}$ & $0.92-1.02$ & 0.996 & 98 & $1.11 \mathrm{~B}$ & $1.01-1.23$ & 0.993 & $0.956 \mathrm{D}$ & $0.891-1.020$ \\
\hline & Bw2 & $1.75 \mathrm{D}$ & $1.64-1.86$ & 0.993 & 547 & $1.01 \mathrm{~B}$ & $0.84-1.22$ & 0.985 & $1.263 \mathrm{C}$ & $1.136-1.390$ \\
\hline \multirow[t]{3}{*}{ Entisol } & A & $2.14 \mathrm{E}$ & $1.95-2.33$ & 0.987 & 153 & $2.24 \mathrm{~A}$ & $1.84-2.74$ & 0.969 & $0.970 \mathrm{~A}$ & $0.828-1.111$ \\
\hline & $\mathrm{Cl}$ & $7.51 \mathrm{~F}$ & $6.49-8.53$ & 0.968 & 1029 & $5.53 \mathrm{C}$ & $4.52-6.78$ & 0.962 & 1.209 BC & $1.012-1.406$ \\
\hline & $\mathrm{C} 2$ & $15.53 \mathrm{G}$ & $12.20-18.86$ & 0.925 & 3235 & $8.87 \mathrm{D}$ & $6.49-12.13$ & 0.894 & $1.478 \mathrm{E}$ & $1.063-1.892$ \\
\hline
\end{tabular}

${ }^{a}$ linear sorption coefficient; ${ }^{h} \mathrm{Kd}$ normalized for organic carbon; ' Freunlich sorption coefficient; ${ }^{d}$ linearity.

respectively. The clay mineral composition of Entisol was not determined.

Sorption of acetamiprid, carbendazim, diuron and thiamethoxam were evaluated quantitatively by the Freundlich and Linear isotherms, whose results are shown in Tables 2 to 5 . Decreasing $\mathrm{K}_{d}$ values for diuron, carbendazim and acetamiprid with depth in the Oxisol was observed, except in the Bw2 horizon, in which the $\mathrm{K}_{d}$ values for diuron and acetamiprid increased. In Entisol, inverse tendency was observed; i.e. an increasing sorption $\left(\mathrm{K}_{d}\right)$ of acetamiprid, diuron and thiamethoxam with depth, except for carbendazim, for which $\mathrm{K}_{d}$ reduced in subsurface.

The $\mathrm{K}_{d}$ values for acetamiprid showed significant ( $\mathrm{p}=$ 0.05 ) difference among all horizons in both soils (Table 2). In $\mathrm{Ap}$ and $\mathrm{A} / \mathrm{B}$ horizons, no significant difference in $\mathrm{K}_{f}$ values was observed, as well as in Bw1 and Bw2 horizons. The sorption coefficients of this pesticide showed no correlation with soil attributes (Pearson correlation).

The carbendazim $\mathrm{K}_{d}$ values in $\mathrm{A} / \mathrm{B}$ and $\mathrm{Bwl}$ horizons were significantly $(\mathrm{p}<0.05)$ different from Ap and Bw2 horizons of the Oxisol (Table 3 ). The $\mathrm{K}_{f}$ values showed statistical difference $(\mathrm{p}<0.05)$ among all the horizons of the Oxisol and no statistical difference was found between the $\mathrm{C} 1$ and $\mathrm{C} 2$ horizons of the Entisol. Comparing the $\mathrm{Kf}$ values between the two soils, a similar sorption was verified in the surface horizon of the Entisol and in the two top horizons of the Oxisol (Ap and A/B). The sorption of this pesticide reduced in deeper horizons of the Oxisol profile. In the two top horizons of the two soils, carbendazim showed larger sorption in relation to the other studied pesticides (Figs. 2 and 3).

The $\mathrm{K}_{o c}$ values for carbendazim (Table 3) showed little variation among the horizons of Oxisol, with higher value $\left(1716 \mathrm{~mL} \mathrm{~g}^{-1} \mathrm{OC}\right)$ in the Ap horizon, while in the Entisol the sorption was larger in the $\mathrm{C} 2$ horizon $\left(\mathrm{K}_{o c}=2640 \mathrm{~mL} \mathrm{~g}^{-1}\right.$ $\mathrm{OC})$. Those values were in agreement with those found by Nemeth-Konda et al. ${ }^{[16]}$, who found a $\mathrm{K}_{o c}$ of $2805 \mathrm{~mL} \mathrm{~g}^{1} \mathrm{OC}$ for this pesticide. Silva and Melo ${ }^{[29]}$ observed that sorption of carbendazim in a turf soil depended on the organic matter content in higher extent than on clay content. Berglö et al ${ }^{[13]}$ studied the carbendazim sorption in Vietnamese soils with physical and chemical properties similar to the soil used here and found $\mathrm{K}_{o c}$ values that ranged from 960 to $2700 \mathrm{~mL} \mathrm{~g}^{-1}$.

The sorption coefficient $\mathrm{K}_{f}$ for carbendazim presented a correlation highly significant $\left(\mathrm{r}^{2}=0.82\right.$ and $\left.\mathrm{p}<0.01\right)$ with OC content in both soils, being the same verified to $\mathrm{K}_{d}$ values, but with less significance $\left(r^{2}=0.97\right.$ and $\left.p<0.05\right)$. This was confirmed by the reduction in sorption coefficients with the decrease of organic carbon content deeper down the soil profile (Table 3 ). To the other soil attributes, no correlation was verified. Berglöf et al ${ }^{[13]}$ also observed significant

Table 3. Carbendazim sorption parameters for Freundlich and Linear models with confidence interval. Different capital letters within each column denote significant differences at $\mathrm{p}<0.05$ (Kruskal-Wallis non-parametric test)

\begin{tabular}{|c|c|c|c|c|c|c|c|c|c|c|}
\hline Soil & Hor. & $\begin{array}{c}K d^{a} \\
m L g^{-1}\end{array}$ & IC $95 \%$ & $r^{2}$ & $\begin{array}{c}K o c^{b} \\
m L g^{-1}\end{array}$ & $\begin{array}{c}K f^{c} \\
\mu g^{1-1 / n} g^{-1} m L^{1 / n}\end{array}$ & IC $95 \%$ & $r^{2}$ & $1 / n^{d}$ & IC $95 \%$ \\
\hline \multirow[t]{4}{*}{ Oxisol } & Ap & $26.77 \mathrm{~A}$ & $23.23-30.31$ & 0.974 & 1716 & $34.51 \mathrm{~A}$ & $30.20-39.45$ & 0.977 & $0.602 \mathrm{AB}$ & $0.519-0.685$ \\
\hline & $\mathrm{A} / \mathrm{B}$ & $15.05 \mathrm{BC}$ & $12.62-17.48$ & 0.962 & 1024 & $25.88 \mathrm{~B}$ & $21.98-30.41$ & 0.954 & $0.453 \mathrm{~A}$ & $0.363-0.542$ \\
\hline & Bw1 & $15.51 \mathrm{BD}$ & $13.78-17.24$ & 0.978 & 1567 & $19.82 \mathrm{D}$ & $17.58-22.34$ & 0.976 & $0.776 \mathrm{~B}$ & $0.677-0.875$ \\
\hline & $\mathrm{Bw} 2$ & $3.66 \mathrm{~F}$ & $3.41-3.91$ & 0.991 & 1144 & $1.89 \mathrm{E}$ & $1.27-2.80$ & 0.934 & $1.395 \mathrm{CE}$ & $1.092-1.698$ \\
\hline \multirow[t]{3}{*}{ Entisol } & A & $31.09 \mathrm{~A}$ & $28.73-33.45$ & 0.993 & 2221 & $29.11 \mathrm{AB}$ & $24.39-34.83$ & 0.952 & $1.165 \mathrm{D}$ & $0.904-1.495$ \\
\hline & $\mathrm{Cl}$ & $13.00 \mathrm{CE}$ & $11.46-14.54$ & 0.979 & 1781 & $8.07 \mathrm{C}$ & $6.95-9.40$ & 0.981 & $1.405 \mathrm{CD}$ & $1.230-1.580$ \\
\hline & $\mathrm{C} 2$ & $12.69 \mathrm{DE}$ & $11.73-13.65$ & 0.990 & 2644 & $8.91 \mathrm{C}$ & $7.67-10.35$ & 0.975 & $1.317 \mathrm{DE}$ & $1.145-1.489$ \\
\hline
\end{tabular}

${ }^{a}$ linear sorption coefficient; ${ }^{b} \mathrm{Kd}$ normalized for organic carbon; ${ }^{c}$ Freunlich sorption coefficient; “linearity. 

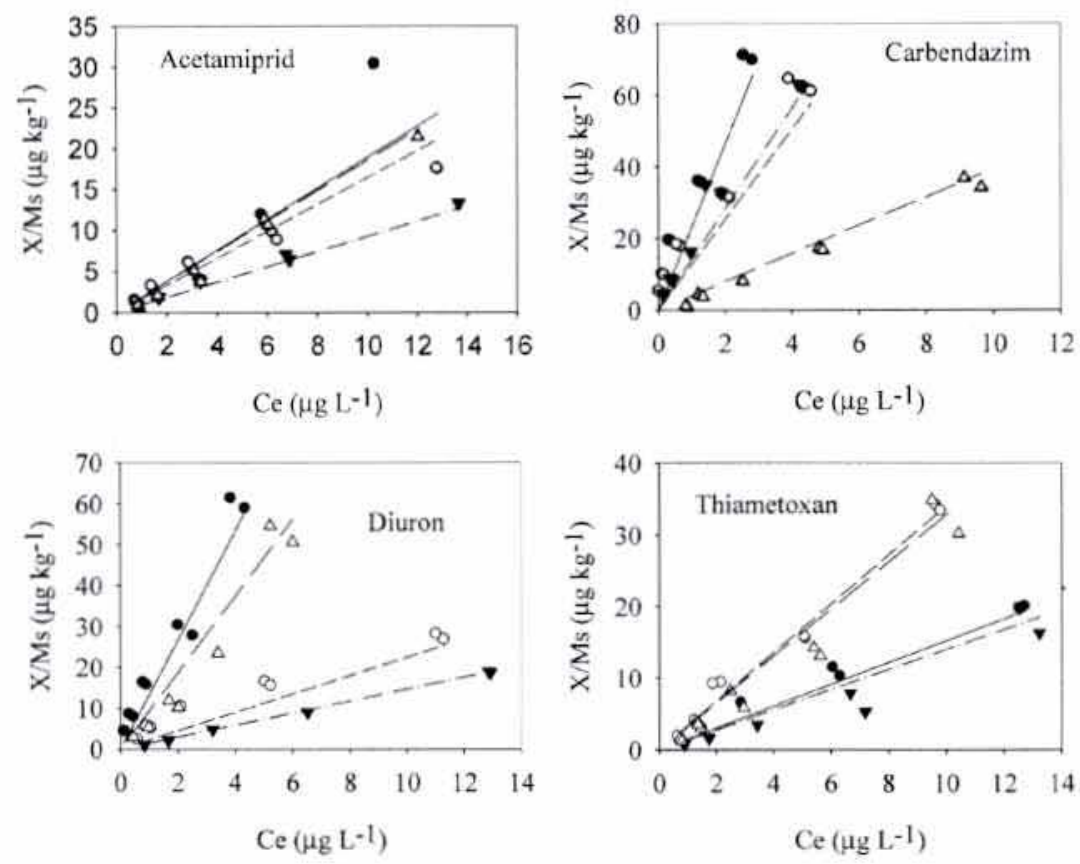

\begin{tabular}{cl}
$\bullet$ & $\mathrm{Ap}$ \\
0 & $\mathrm{~A} / \mathrm{B}$ \\
$\mathbf{\nabla}$ & $\mathrm{Bw1}$ \\
$\Delta$ & $\mathrm{Bw} 2$ \\
\hdashline$-\cdots$ & $\mathrm{Ap}$ \\
$-\cdots$ & $\mathrm{A} / \mathrm{B}$ \\
$--\cdots$ & $\mathrm{Bw} 1$ \\
$--\cdots$ & $\mathrm{Bw} 2$ \\
\hline
\end{tabular}

Fig. 2. Linear sorption isoterms for acetamiprid, carbendazim, diuron and thiamethoxam in the horizons of Oxisol.

correlation among sorption coefficients of carbendazim and the OC content. However, they verified positive correlation between $\mathrm{K}_{f}$ and $\mathrm{K}_{d}$ with soil clay content, a fact that was not observed in our study.

The $\mathrm{K}_{d}$ and $\mathrm{K}_{f}$ values for diuron showed significant ( $\mathrm{p}=$ 0.05 ) difference among the two soil horizons, except to $\mathrm{K}_{f}$ values in the Oxisol A/B horizon and Entisol $\mathrm{Cl}$ horizon. Sorption of diuron was larger in the Ap horizon of the Oxisol, being the opposite observed in the Entisol (Table 4). The $\mathrm{K}_{o c}$ values of the diuron ranged from 145 to $2631 \mathrm{~mL}$ $\mathrm{g}^{-1} \mathrm{OC}$ (mean, 968), indicating intermediary mobility. Similar results were found by Souza et al. ${ }^{[14]}$ and Caracciolo et al. ${ }^{[30]}$ while Liyanage et al..$^{[15]}$ and Oliver et al. ${ }^{[12]}$ observed lower values of $\mathrm{Koc}$, varying from 55 to $962 \mathrm{~mL} \mathrm{~g}^{-1}$ (mean, 407 ) and 225 to $1179 \mathrm{~mL} \mathrm{~g}^{-1}$ (mean of 599), respectively.

No correlation between $\mathrm{K}_{f}$ and $\mathrm{K}_{d}$ values with soil attributes were observed, while $\mathrm{K}_{o c}$ showed positive correlation $\left(\mathrm{r}^{2}=0.897 ; \mathrm{p}=0.006\right)$ with clay/OC ratio. This result diverges from the one observed by Souza et al. ${ }^{[14]}$ who found positive correlation of $\mathrm{K}_{f}$ and $\mathrm{K}_{o c}$ only with organic carbon of an Ultisol. According to Karickhoff ${ }^{[36]}$ for a mineral/ organic carbon ratio of less than 30 , mineral contributions for sorption can be reduced, despite clay content, probably due to mineral blockage by the organic matter. ${ }^{[37]}$

The generalization that appears in the literature is that the most important soil property affecting sorption of pesticides is the OC content. Non-hydrophobic interactions, nevertheless, can contribute to the sorption under some conditions. This appears to occur with highly polar or ionizable compounds and is more apparent for soils with low OC and high clay content. ${ }^{[38]}$

The mechanisms involved in the sorption of pesticides to organic matter have not been clearly demonstrated. Soil organic matter is a complex and heterogeneous mixture of humic substances, polysaccharides, lignin, simple carbohydrates, lipids, proteins and organic acids, and can be associated to aluminum-silicates, aluminum and iron hydroxide, and other inorganic compounds in soil. ${ }^{[27.38 .39]}$ Hence, not only the organic matter content but also its composition influences sorption.

The thiamethoxam sorption (Table 5) in the Oxisol was variable, with similar values in $\mathrm{A} / \mathrm{B}$ and $\mathrm{Bw} 2$ horizons. However, in the Entisol $\mathrm{K}_{d}$ and $\mathrm{K}_{f}$ showed significant difference $(\mathrm{p}<0.05)$ between $\mathrm{Ap}, \mathrm{Cl}$ and $\mathrm{C} 2$ horizons. No 

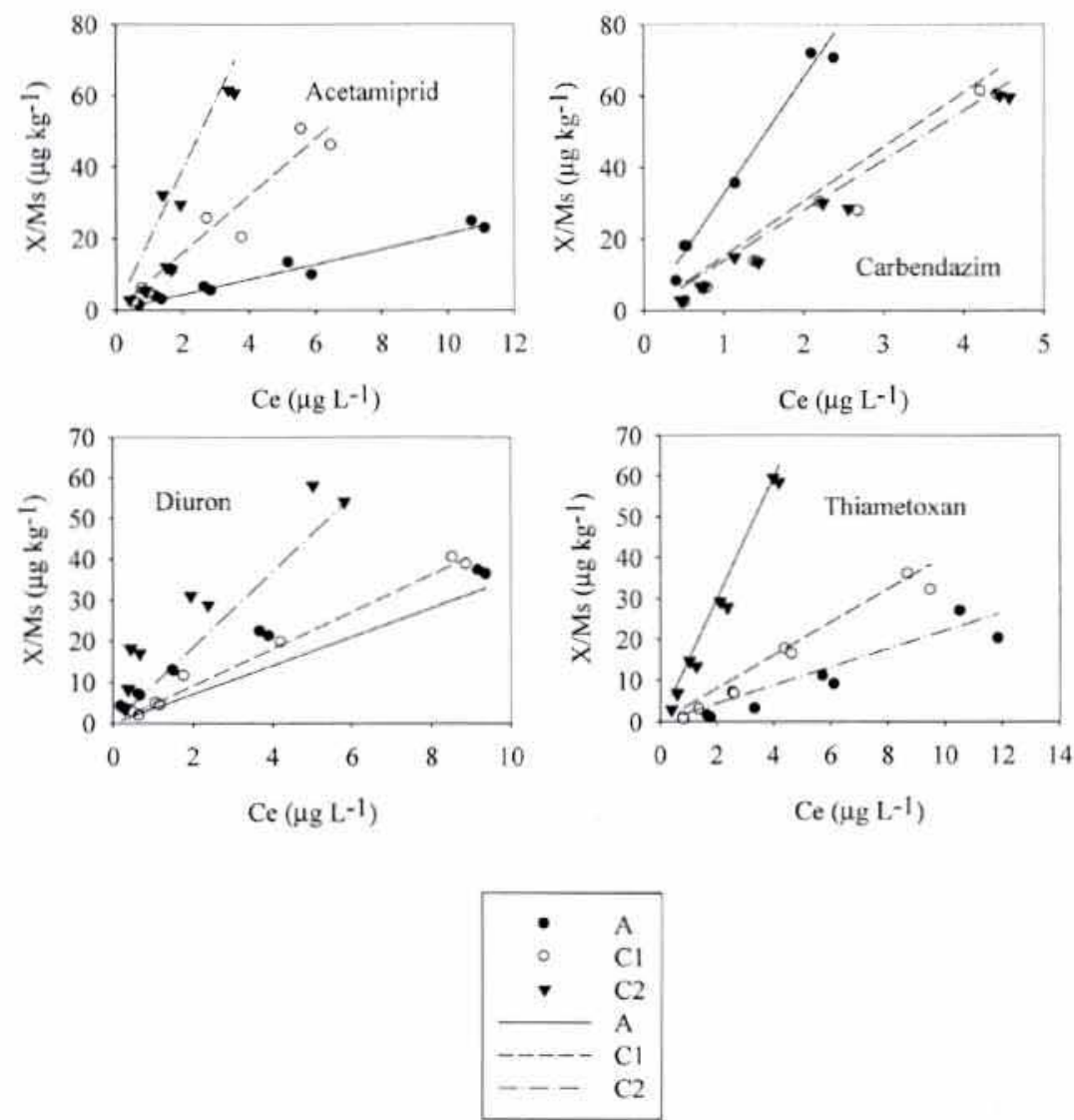

Fig. 3. Linear sorption isoterms for acetamiprid, carbendazim, diuron and thiamethoxam in the Entisol horizons.

correlation of sorption coefficient of this pesticide with soil attributes was observed. Campbell et al. ${ }^{[31]}$ studied the thiamenthoxam sorption in two Hawaiian soils, where $\mathrm{K}_{\text {, val- }}$ ues of 0.71 and $2.82 \mu \mathrm{g}^{1-1 / n} \mathrm{~g}^{-1} \mathrm{~mL}^{1 / n}$ were obtained. These values are similar to those found in the horizons in the $\mathrm{Ox}$ isol and in the two first horizons of the Entisol.

The linearity of sorption isotherm represented by $1 / \mathrm{n}$ from Freundlich equation was verified testing the hypothesis $1 / \mathrm{n} \bullet 1$ for each soil horizon, using the Student's $t$ test (Table 6). For the horizons where the hypothesis $1 / n \bullet 1$ was rejected, pesticides sorption coefficients were independent on solution concentration, being observed with higher frequency for acetamiprid and thiamethoxam. That behavior is more common when sorption occurs by hydrophobic process $^{[40]}$, or the pesticide concentration range used in the sorption test was not sufficient to identify the isotherm type.

Table 4. Diuron sorption parameters for Freundlich and Linear models with confidence interval. Different capital letters within each column denote significant differences at $\mathrm{p}<0.05$ (Kruskal-Wallis non-parametric test)

\begin{tabular}{|c|c|c|c|c|c|c|c|c|c|c|}
\hline Soil & Hor. & $\begin{array}{c}K d^{a} \\
m L g^{-1}\end{array}$ & IC $95 \%$ & $r^{2}$ & $\begin{array}{c}K o c^{b} \\
m L g^{-1}\end{array}$ & $\begin{array}{c}K f^{c} \\
\mu g^{1-1 / n} g^{-1} m L^{1 / n}\end{array}$ & IC $95 \%$ & $r^{2}$ & $1 / n^{d}$ & IC $95 \%$ \\
\hline \multirow[t]{4}{*}{ Oxisol } & Ap & $14.31 \mathrm{~A}$ & $12.80-15.82$ & 0.981 & 917 & $18.07 \mathrm{~B}$ & $15.96-20.46$ & 0.974 & $0.748 \mathrm{~A}$ & $0.647-0.848$ \\
\hline & $A / B$ & $2.65 \mathrm{~B}$ & $2.27-3.03$ & 0.965 & 180 & $4.29 \mathrm{~A}$ & $3.50-5.25$ & 0.953 & $0.818 \mathrm{AB}$ & $0.670-0.967$ \\
\hline & Bw1 & $1.44 \mathrm{C}$ & $1.41-1.47$ & 0.999 & 145 & $1.27 \mathrm{C}$ & $1.20-1.35$ & 0.998 & $1.058 \mathrm{D}$ & $1.021-1.095$ \\
\hline & Bw2 & $8.42 \mathrm{D}$ & $7.25-9.59$ & 0.967 & 2631 & $6.65 \mathrm{D}$ & $5.65-7.83$ & 0.971 & $1.091 \mathrm{C}$ & $0.936-1.246$ \\
\hline \multirow[t]{3}{*}{ Entisol } & A & $4.34 \mathrm{E}$ & $3.58-5.10$ & 0.950 & 310 & $9.25 \mathrm{E}$ & $8.51-10.02$ & 0.986 & $0.629 \mathrm{E}$ & $0.569-0.690$ \\
\hline & $\mathrm{C}_{1}$ & $4.58 \mathrm{~F}$ & $4.28-4.88$ & 0.995 & 627 & $4.26 \mathrm{~A}$ & $3.22-5.61$ & 0.957 & $1.054 \mathrm{BC}$ & $0.832-1.277$ \\
\hline & $\mathrm{C}_{2}$ & $10.99 \mathrm{G}$ & $8.95-13.03$ & 0.943 & 2290 & $16.37 \mathrm{~F}$ & $12.08-22.18$ & 0.849 & $0.790 \mathrm{BC}$ & $0.519-1.061$ \\
\hline
\end{tabular}

${ }^{a}$ linear sorption coefficient; ${ }^{b} \mathrm{Kd}$ normalized for organic carbon; ${ }^{\circ}$ Freunlich sorption coefficient; ${ }^{\prime}$ linearity. 
Table 5. Thiamethoxam sorption parameters for Freundlich and Linear models with confidence interval. Different capital letters within each column denote significant differences at $\mathrm{p}<0.05$ (Kruskal-Wallis non-parametric test)

\begin{tabular}{|c|c|c|c|c|c|c|c|c|c|c|}
\hline Soil & Hor. & $\begin{array}{c}K d^{a} \\
m L g^{-1}\end{array}$ & IC $95 \%$ & $r^{2}$ & $\begin{array}{c}K o c^{b} \\
m L g^{-1}\end{array}$ & $\begin{array}{c}K f^{c} \\
\mu g^{1-1 / n} g^{-1} m L^{1 / n}\end{array}$ & IC $95 \%$ & $r^{2}$ & $I / n^{d}$ & IC $95 \%$ \\
\hline \multirow[t]{4}{*}{ Oxisol } & Ap & $1.63 \mathrm{~B}$ & $1.52-1.74$ & 0.992 & 104 & $2.02 \mathrm{~A}$ & $1.72-2.38$ & 0.984 & $0.924 \mathrm{~A}$ & $0.818-1.031$ \\
\hline & $\mathrm{A} / \mathrm{B}$ & $3.41 \mathrm{~A}$ & $3.20-3.62$ & 0.993 & 232 & $3.16 \mathrm{C}$ & $2.61-3.85$ & 0.971 & $1.052 \mathrm{ABC}$ & $0.902-1.201$ \\
\hline & Bwl & $1.27 \mathrm{C}$ & $1.25-1.29$ & 0.958 & 128 & $0.86 \mathrm{~B}$ & $0.70-1.08$ & 0.977 & $1.131 \mathrm{BD}$ & $0.990-1.272$ \\
\hline & Bw2 & $3.02 \mathrm{~A}$ & $2.64-3.40$ & 0.972 & 944 & $2.07 \mathrm{~A}$ & $1.65-2.59$ & 0.971 & $1.170 \mathrm{~B}$ & $1.005-1.335$ \\
\hline \multirow[t]{3}{*}{ Entisol } & A & $1.92 \mathrm{D}$ & $1.88-1.96$ & 0.940 & 137 & $0.7 \mathrm{~B}$ & $0.47-1.06$ & 0.956 & $1.419 \mathrm{DE}$ & $1.148-1.690$ \\
\hline & $\mathrm{C}_{1}$ & $3.61 \mathrm{E}$ & $3.22-4.00$ & 0.980 & 495 & $1.37 \mathrm{D}$ & $1.02-1.84$ & 0.968 & $1.554 \mathrm{E}$ & $1.325-1.783$ \\
\hline & $\mathrm{C}_{2}$ & $13.81 \mathrm{~F}$ & $12.77-14.85$ & 0.992 & 2877 & $11.14 \mathrm{E}$ & $9.64-12.88$ & 0.976 & $1.195 \mathrm{CD}$ & $1.026-1.364$ \\
\hline
\end{tabular}

alinear sorption coefficient; ${ }^{b} \mathrm{Kd}$ normalized for organic carbon; 'Freunlich sorption coefficient; ${ }^{d}$ linearity.

For carbendazim sorption to the first three horizons and for diuron to the first two horizons of Oxisol, the $1 / \mathrm{n}$ constant was smaller than 1 , showing that the sorption coefficient of those pesticides decrease as solution concentration increases, which is characteristic for polar molecules and for cationic forms of basic compounds such as carbendazim $\left(\mathrm{pK}_{b}=4.2\right)$. The same was observed for diuron in Ap horizon of the Entisol. For the other horizons of the two studied soils in which the constant $1 / \mathrm{n}$ was higher than 1 , an increase in sorption coefficients as the pesticides concentrations in solution increase was observed, representing the initial part of an $S$ type isotherm. ${ }^{[4]]}$

In Entisol, the sorption of carbendazim was linear only in the A horizon with high $\mathrm{OC}$ content. The opposite was observed in the $\mathrm{C} 1$ and $\mathrm{C} 2$ horizons, where the organic carbon content was smaller, indicating a change in sorption mechanism.

Linear sorption of acetamiprid was observed in almost all horizons of the Oxisol, except in $\mathrm{Bw} 2$ and in the A horizon of Entisol. In the horizons where OC content was equal or higher than $1 \%$, the sorption behavior of this pesticide was linear; on the other hand in the horizons with OC content lesser than $0.73 \%$ the sorption was non-linear. Thus, either

Table 6. Statistical analysis of the hypothesis of $1 / n \neq 1$ by Student's $t$ test

\begin{tabular}{lcccc}
\hline \multicolumn{5}{c}{ Pesticides } \\
\cline { 2 - 5 } Horizons & Acetamiprid & Carbendazim & Diuron & Thiamethoxam \\
\hline \multicolumn{5}{c}{ Oxisol } \\
Ap & NS $^{a}$ & $<1$ & $<1$ & NS \\
A B & NS & $<1$ & $<1$ & NS \\
Bw1 & NS & $<1$ & $>1$ & NS \\
Bw2 & $>1$ & $>1$ & NS & $>1$ \\
& NS & Entisol & & \\
A & $>1$ & NS & $<1$ & $>1$ \\
C1 & $>1$ & $>1$ & NS & $>1$ \\
C2 & $>1$ & NS & $>1$ \\
\hline
\end{tabular}

${ }^{a} \mathrm{NS}=$ not significant at $\mathrm{p}<0.05$, mineral fraction contributes significantly to retention of this pesticide or its molecules were sorbed by specific sites of the organic matter. ${ }^{[39]}$

For diuron, in the three horizons with low OC content $(<1 \%)$ sorption data behaved linearly while for OC larger than $1.4 \%, 1 / \mathrm{n}$ was less than 1 and for OC content approximately $1,1 / \mathrm{n}$ was greater than 1 . Sheng et al. ${ }^{[19]}$ observed non-linearity of the sorption isotherm for low concentrations of this pesticide in a silt loam soil with $1.2 \% \mathrm{CO}$.

Thiamethoxam showed linear behavior in all horizons of the Oxisol, except in the Bw2, with a value of $1 / \mathrm{n}$ higher than 1 in this horizon and in all horizons of the Entisol. This pesticide showed low sorption interaction with soil constituents, particularly in the Oxisol. No correlation of sorption coefficients with attributes of soils was observed, corroborating the low sorption showed by this pesticide in the horizons of both studied soils.

For the studied pesticides, among the horizons of both soils a variation up to 30 times in Koc values was observed. This, in addition to the probable change in sorption mechanism as a function of organic carbon content, brings doubts about the applicability of this coefficient to evaluate the potential of groundwater contamination.

\section{Conclusions}

The studied pesticides showed dissimilar sorptive behavior in Oxisol and Entisol. Acetamiprid and thiamethoxam showed low sorption coefficients, indicating greater potential of contamination of ground and surface water. The pesticides sorption in the Oxisol horizons decrease with depth, while in Entisol an increase in sorption was observed in deeper horizons, except for carbendazim.

Significant correlation of the sorption of carbendazim with soil organic carbon content in the horizons of Oxisol and Entisol was observed. The sorption coefficients of acetamiprid, thiamethoxam and diuron showed no significant correlation with soil organic carbon content, indicating that interaction of these pesticides with the mineral constituents 
of the Oxisol and Entisol might play an important role in the sorption process.

\section{Acknowledgments}

L. Carbo thanks Conselho Nacional de Desenvolvimento e Tecnológico $(\mathrm{CNPq})$ for fellowship and the authors thank Fundo de Apoio à Cultura do Algodão (FACUAL) for financial support.

\section{References}

[1] Frighetto, R.T. Impacto ambiental decorrente do uso de pesticidas agricolas. In Microbiologia Ambiental; Melo, I. S., Azevedo, J. L., Eds.; EMBRAPA: Jaguariúna, 1997; 415-438.

[2] Nunes, M.V.; Tajara, E.H. Efeitos tardios dos praguicidas organoclorados no homem. Rev. Saúde Pública 1998, 32(4), 372-383.

[3] Dores, E.F.G.C.; De-Lamonica-Freire, E.M. Contaminação do ambiente aquático por pesticidas: Vias de contaminação e dinâmica dos pesticidas no ambiente aquático. Pesticidas: R. Ecotoxicol. e Meio Ambiente 1999, 9, 1-18.

[4] Rieder, A.; Dores, E.F.G.C.; Higa, N.; Moraes, M.P.L. Alteraçōes no teor de matéria orgânica de solos e provável efeito no poder de proteção ambiental nas bordas do Pantanal diante da poluição por pesticidas. Pesticidas: R. Ecotoxicol. e Meio Ambiente 2000, 10, 87-112.

[5] Araújo, A.C.P; Nogueira, D.P; Augusto, L.G.S. Impacto dos praguicidas na saúde: estudo da cultura de tomate. Rev. Saúde Pública 2000, 34(3), 309-313.

[6] Marques, P.R.B.O.; Nunes, G.S.; Queiroz, M.E.R.; Orlanda, J.F.F; SOUSA, H.S. Análise de pesticidas em amostras ambientais oriundos da barragem de Boa Esperança (PL/MA BRASIL): Avaliação preliminar. Pesticidas: R. Ecotoxicol. e Meio Ambiente 2002, 12, $13-30$.

[7] Cocco, P. On the rumors about the silent spring. Review of the scientific evidence linking occupational and environmental pesticide exposure to endocrine disruption health effects. Cad. Saúde Pública 2002, 18(2), 379-402.

[8] Carter, A.D. Herbicide movement in soils: principles, pathways and processes. Weed Res, 2000, 40, 113-122.

[9] Site, A.D. Factors affecting sorption of organic compounds in natural sorbent/ Water systems and sorption coefficients for selected pollutants. A review. J. Phys. Chem. Ref. Data 2001, 30(1), 187-253.

[10] Monteiro, R.T. Degradação de pesticidas. In Microbiologia Ambiental; Melo, I.S., Azevedo, J.L., Eds; EMBRAPA: Jaguariủna, 1997; $125-140$.

[11] Spadotto, C.A.; Filizola, H.; Gomes, M.A.F. Avaliação do potencial de lixiviação de pesticidas em Oxisol da região de Guairá. Pesticidas: R. Ecotoxicol. e Meio Ambiente 2001, II, 127-136.

[12] Oliver, D.P.; Kookana, R.S; Quintana, B. Sorption of pesticides in tropical and temperate soils from Australia and the Philippines. J. Agric. Food Chem. 2005, 53, 6420-6425.

[13] Berglof, T.; Dung, T.V.; Kylin, H.; Nilsson, I. Carbendazim sorptiondesorption in Vietnamese soils. Chemosphere 2002, 48, 267-273.

[14] Souza, M.D.; Boeira, R.C.; Gomes, M.A.F. Adsorção e dessorção de diuron em solos tropicais. Pesticidas: R. Ecotoxicol. e Meio Ambiente 2000, 10, 113-124.

[15] Liyanage, J.A.; Watawala, R.C.; Aravinna, A.G.P.; Smith, L.; Kookana, R.S. Sorption of carbofuran and diuron pesticides in 43 tropical soils of Sri Lanka. J. Agric. Food Chem. 2006, 54, 1784 1791.
[16] Nemeth-Konda, L.; Füleky, G.Y;; Morovjan, G.Y.; Csokan, P. Sorption behaviour of acetochlor, atrazine, carbendazim, diazinon, imidacloprid and isoproturon on Hungarian agricultural soil. Chemosphere 2002, 48, 545-552.

[17] Spadotto, C.A.; Hornsby, A.G. Organic compounds in the environment. Soil sorption of acidic pesticides: Modeling pH effects. J. Environ. Qual. 2003, 32, 949-956.

[18] Weber, J.B.; Wilkerson, G.G.; Reinhardt, C.F. Calculating pesticide sorption coefficients $(\mathrm{Kd})$ using selected soil properties. Chemosphere 2004, 55, 157-166.

[19] Sheng, G.; Yang, Y.; Huang, M.; Yang, K. Influence of pH on pesticide sorption by soil containing wheat residue-derived char. Environ. Pollut. 2005, 134, 457-463.

[20] Yu, Y; Zhou, Qi-Xing. Adsorption characteristic of pesticides methamidophos and glyphosate by two soils. Chemosphere 2005, $58,811-816$.

[21] Madhun, Y.A.; Freed, V.H.; Young, J.L.; Fang, S.C. Sorption of bromacil, chlortoluron, and diuron by soils. Soil Sci. Soc. Am. J. $1986,50(6), 1467-1471$.

[22] Mandal, A.K.; Adhikari, M. Role of organic matter and sesquioxides in the adsorption of pesticides on soils. J. Ind. Soc. Soil Sci. $1995,43(4), 561-567$.

[23] Moraes, S.L.; Rezende, M.O.O. Comportamento sortivo dos herbicidas s-triazinas $\mathrm{em}$ solo e em ácidos húmicos. R. Ecotoxicol. $\mathrm{c}$ Meio Ambiente 1998, 8, 157-170.

[24] Vieira, E.M.; Prado, A.G.S.; Landgraf, M.D.; Rezende, M.O.O Estudo da adsorção/dessorção do ácido 2,4 diclorofenoxiacético (2,4D) em solo na ausência e presença de matéria orgânica. Quim. Nova 1999, 22(3), 305-308.

[25] Wei, J.; Furrer, G.; Kaufmann, S.; Schulin, R. Influence of clay minerals on the hydrolysis of carbamate pesticides. Environ. Sci. Technol. 2001, 35, 2226-2232.

[26] Szeto, S.Y.; Price, P.M. Persistence of pesticide residues in mineral and organic soils in the Fraser Valley of British Columbia. J. Agric. Food Chem. 1991, 39, 1679-1684.

[27] Sheng, G.; Johnston, C.T.; Teppen, B.J.; Boyd, S. Potential contributions of smectite clays and organic matter to pesticide retention in soils. J. Agric. Food Chem. 2001, 49(6), 2899-2907.

[28] Daniel, P.E.; Bedmar, F.; Costa, J.L.; Aparicio, V.C. Atrazine and metribuzin sorption in soils of the Argentinean humid pampas. Environ. Toxicol. Chem. 2002, 2I(12), 2567-2572.

[29] Silva, C.M.M.S.; Melo, I.S. Degradação de fungicidas benzimidazóis. In Microbiologia Ambiental; Melo, I.S., Azevedo, J.L., Eds.; EMBRAPA: Jaguariúna, 1997; 141-165.

[30] Caracciolo, A.B.; Giuliano, G.; Grenni, P.; Guzzella, L.; Pozzone, F. Bottoni, P.; Fava, L.; Crobe, A.; Orrú, M.; Funari, E. Degradation and leaching of the herbicides metolachlor and diuron: a case study in an area of Northern Italy. Environ. Pollut. 2005, 134, 525-534.

[31] Campbell, S.; Chen, L.; Yu, J.; Li, Q.X. Adsorption and analysis of the insecticides thiamethoxam and indoxacarb in Hawaiian soils. J. Agric. Food Chem. 2005, 53, 5373-5376.

[32] EMBRAPA - Empresa Brasileira de Pesquisa Agropecuária, Serviço Nacional de Levantamento e Conservação de Solos. Manual de métodos de análises de solos. Embrapa: Rio de Janeiro, 1997.

[33] Pradas, E.G.; Sanchez, M.V.; Perez, M.F.; Viciana, M.S.; Amate, M.D.U. Sorption and leaching of diuron on natural and peatamended calcareous soil from Spain. Water Res. 1998, 32 (9), 2814. 2820 .

[34] Gaillardon, P.; Dur, J.C. Influence of soil moisture on short-term adsorption of diuron and isoproturon by soil. Pest. Sci. 1995, 45, 297-303.

[35] Inoue, M.H.; Oliveira, Jr., R.S.; Regitano, J.B.; Tormena, C.A.; Constantin, J.; Tornisielo, V.L. Sorption kinetics of atrazine and diuron in soils from southern Brazil. J. Environ. Sci. Health, Part B 2004, 39(4), $589-601$.

[36] Karickhoff, S.W. Organic pollutant sorption in aquatic systems. J. Hydraul. Eng. 1984, 110, 707-735. 
[37] Walker, A.; Crawford, D.V. The role of organic matter in adsorption of the triazine herbicides by soils. In Proc. 2nd Int. Symp. Isotopes and Radiation in Soil Organic Matter Studies, July 15-19, 1968. International Atomic Energy Agency, Vienna, Austria. 1968; p. 91-108

[38] Stevenson, F. J. Humus Chemistry - genesis, composition, reactions, 2nd Ed., John Wiley \& Sons: New York, 1994; p. 496.

[39] Ahmad, R.; Kookana, R.S.; Alston, A. M.; Skjemstad, J.O. The nature of soil organic matter affects sorption of pesticides. 1 .
Relationship with carbon chemistry as determined by ${ }^{13} \mathrm{c}$ CP. MAS NMR spectroscopy. Environ. Sci. Technol. 2001, 35, 878 884.

[40] McBride, M. B. Environmental chemistry of soils, Oxford Univ. Press: New York, 1994.

[41] Falone, S.Z.; Vieira, E.M. Adsorção/Dessorção do explosivo tetril em turfa e em Argissolo Vermelho Amarelo. Quim. Nova 2004, $27(6), 849-854$. 